\title{
DISCOURSE OF THE COLLECTIVE SUBJECT: SOCIAL REPRESENTATIONS AND COMMUNICATION INTERVENTIONS
}

\author{
Fernando Lefevre ${ }^{1}$, Ana Maria Cavalcanti Lefevre ${ }^{2}$
}

${ }^{1}$ Ph.D. in Public Health; senior full professor, School of Public Health, University of São Paulo (USP), SP, Brazil. E-mail: flefevre@usp.br

2 Ph.D. in Public Health; managing partner and researcher at the Institute for Research on Collective Subject (IPDSC, for Instituto para Pesquisa sobre o Sujeito Coletivo), SP, Brazil. E-mail: alefevre@usp.br

\begin{abstract}
We present herein the Discourse of the Collective Subject method as a way to retrieve social representations. We sought to reconstitute these social representations through DCS maintaining the link between their individual and collective dimensions. The Discourse of the Collective Subject were obtained through an empirical study and they are herein called speaking and spoken products. They are speaking products because social representations are discursive practices, current behaviors of social agents. They are also spoken products because society (or the others), while socially-shared cognitive schemes, are always present in individual speeches. The social representations reconstructed by Discourse of the Collective Subject allow common people to identify with them, enabling its use in practices of social intervention.
\end{abstract}

KEYWORDS: Qualitative research. Methodology. Contraceptives, postcoital.

\section{DISCURSO DO SUJEITO COLETIVO: REPRESENTAÇÕES SOCIAIS E INTERVENÇÕES COMUNICATIVAS}

RESUMO: Apresentamos aqui o método do Discurso do Sujeito Coletivo como um modo de resgatar representações sociais. Através dele, buscamos reconstituir essas representações sociais preservando suas dimensões individual e coletiva articuladas. Os Discurso do Sujeito Coletivo foram obtidos em uma pesquisa empírica e são aqui denominados produtos falando e falado. Eles são produtos falando porque representações sociais são práticas discursivas, comportamentos reais de agentes sociais. Eles são também produtos falados porque a sociedade (ou os "outros"), enquanto esquemas cognitivos 'socialmente compartilhados, estão sempre presentes nas falas individuais. As representações sociais reconstituídas pelo Discurso do Sujeito Coletivo permitem que o sujeito comum se identifique com elas, viabilizando sua utilização em práticas de intervenção social.

PALAVRAS CHAVE: Pesquisa qualitativa. Metodologia. Anticoncepcionais pós-coito

\section{DISCURSO DEL SUJETO COLECTIVO, REPRESENTACIONES SOCIALES INTERVENCIONES COMUNICATIVAS}

RESUMEN: Se presenta el método del Discurso del Sujeto Colectivo como método de rescate de las representaciones sociales. A través de él, se buscó reconstituir dichas representaciones preservando las dimensiones individuales y colectivas articuladas. En este sentido los Discursos del Sujeto Colectivo fueron obtenidos en una investigación empírica y son denominados aquí como productos hablando/ hablado. Las consideramos como productos hablando porque las representaciones sociales son prácticas discursivas, comportamientos habituales de los agentes sociales y son productos hablado porque la sociedad (o el "otro"), como esquemas cognitivos socialmente compartidos, están siempre presentes en los discursos individuales. Las representaciones sociales reconstruidas por Discursos del Sujeto Colectivo permiten que el sujeto común se identifique con ellas, lo que viabiliza su uso en las prácticas de intervención social.

PALABRAS CLAVE: Investigación cualitativa. Metodología. Anticonceptivos post-coito. 


\section{INTRODUCTION}

We present herein the Discourse of the Collective Subject (DCS) method as a way to recover social representations (SR). Through DCS, we sought to reconstruct SR while maintaining the link between their individual and collective dimensions. This text is organized into two main sections. In the first oneing Afterstimuli'selecting one, theoretical and methodological concepts of SR are connected with those of DCS; in the second one, the Morning-After Program (Programa Di@ seguinte), which resulted from an investigation conducted with DCS, is presented as a way to show the possibilities of this method.

\section{RETRIEVAL OF SOCIAL REPRESENTA- TIONS}

\section{Social representation as social-cognitive schemes}

In everyday life, SR are always present in opinions, positions, manifestations, or attitude of an individual, and they constitute the quality of common-sense knowledge ${ }^{1}$.

The possibility of always grouping and reconstituting statements or expressions of individual thoughts into broad categories of meaning is an indication of that.

What are these categories?

Categories are socio-cognitive schemes, ${ }^{2}$ i.e., they are socially-shared ways of knowing, representing, or interacting with the world in everyday life. These modes are present in manifestations of social actors of a given social formation ${ }^{1}$ and reveal the possible consciousness of these actors in a given historical moment.

However, the possibility of grouping or gathering different individual thoughts or opinions in general and inclusive semantic categories does not guarantee that we are in the presence of social representation.

Why?

Before we answer this question, we need to point out that the meaning categories can be of empirical or theoretical nature, or be somewhere between pure empiricism and theory.

The farther away meaning categories are from empiricism, the higher their probability of being linked to interpretive theories. In principle, this separates them from SR, because they are not interpretative theories stricto sensu, but practical entities. In other words, they are knowledge used by individuals or social groups in their ordinary interactions (although frequent vulgarized transformation of large theories, e.g., psychoanalysis, is one of its features). ${ }^{3}$

Thus, SR can be methodologically understood as syntheses close to empiricism, which can be recognized without difficulty by the common sense as "their own", a familiar knowledge.

\section{Social representations and discourses of the collective subject}

The DCS ${ }^{4-5}$ is a way of presenting SR retrieved methodologically with empirical research. In SR, individual opinions or expressions with similar meanings are grouped into general semantic categories, as is usually done with open questions or issues.

Cluster of opinions with similar meanings in corresponding content categories is the differential aspect in the DCS method, although the speeches are different. Thus, a use-synthesis discourse written in the first person singular results from each content group, as if a collectivity were speaking through an individual.

\section{Speaking subject and spoken subject}

This individual/collective is a speaking/ spoken subject. He/she carries, in addition to the SR content adopted personally (speaking) in his/ her discursive practice, ${ }^{6}$ the contents (spoken) of "others", i.e., the semantically equivalent representations available both in that society/culture and adopted by their "representation colleagues".

Thus, a given subject can casually have not used the contents that compose the DCS when he/ she, among others, composes a speaking/spoken DCS. However, we can say that he/she could have used it, since he/she is able to recognize himself/ herself as a social actor in such content.

Therefore, SR in the form of DCS are very close to the opinions as they are actually practiced by groups of social actors.

\section{Collective stories}

We also emphasize that SR, in the form of collective discourses, carry collective stories about 
a given subject or problem, which was investigated when the speeches were subjected to the DCS production process.

Such collective stories reflect or carry socially-shared narrative codes. Therefore, by using content and arguments with similar meaning (although from different speeches), it is possible to construct a credible narrative (in the first person, singular), i.e., an acceptable story for individuals with culture equivalent to that of the subjects surveyed.

The DCS, as collective statements and socially-shared narratives, indicate the way in which SR are "metabolized" by a given society, group, or culture.

\section{Dialectics of abstractions concretized}

However, DCS are far from being a result of mere empiricism. They are concretized abstractions since they are constructed in a dialectical movement in which contents and arguments in individual opinions with a similar meaning are "mined" in individual statements and abstracted to a unifying category. However, DCS remain as DCS contents and arguments despite the abstraction process.

The DCS are individual opinions that pass through the researcher's analytical sieve (requiring the additional use of abstraction and conceptualization operations). The DCS are then transformed into scientifically-treated products, which however maintain the spontaneous characteristics of everyday speech (and are recognizable as such).

The end result of a survey such as DCS (a panel of collective statements) is a construct, an artifact, or a systematic description of that reality, being also a reconstruction (scientific product) of collective thought.

\section{The investigator as an obstetrician of Social Representations}

In the DCS method, the main function of the investigator is to act as an "obstetrician" of SR (or their manifestations), which come in the form of collective discourses.

This is equivalent to saying that giving birth to a collective opinion (like giving birth to a child) is an operation directed by technical experts and involves technology and production.
The product born from such production, either an opinion or a man, is essentially a naturalness. In the case of the opinion, it expresses a manifestation of life in society as a form of existence of gregarious and symbolic animals. Therefore, such opinion is an otherness, a very existence that, leaving the "womb of society", where it was gestated for life (thanks to the expertise of the investigator), it does not belong to the "obstetrician investigator".

\section{Description and interpretation of Social Representations}

This feature of not belonging of the opinion to the investigator allows to clearly understanding the necessary and essential distinction between description and interpretation as chronologically distinct moments of the survey of social representation.

The segment or part of the survey with this feature of not belonging is the description. This allows us to see (by contrast) that interpretation (in which it is asked not what community X thinks, but why it thinks this way and not another) belongs to the investigator, who is no longer the "obstetrician investigator" at this time.

The investigator's face that describes the SR is that of the "obstetrician" and the one that interprets is that of the "inventor" (creator). Therefore, description of a fact is not an invention (creation) of the investigator, but his reconstruction of an existing entity (social fact), even if the fact has a symbolic nature; on the other hand, interpretation (as a creation) is the sole responsibility of the investigator.

However, both functions are equally noble tasks of the investigator, and the acts of attributing meaning are also his. Therefore, the (frequent) characterizations of qualitative investigation (at least the one that has collective beliefs or opinions as their object), as being eminently interpretive, are mistaken when they define interpretation as being synonymous with attribution of meaning (which excludes the task of description).

Since the beginning of the process, knowing SR is an act of attributing meaning. To know SR, it is necessary to describe them and reconstitute them. However, their reconstitution by the investigator is much more than simply observing or detecting its presence. Such reconstitution is 
a specialized task, composed of several actions, choices, and decisions on the topic under study. The clipping performed on the subject, the selection of inductive questions (stimuli), and all tasks related to the processing of the "raw material" (individual statement, newspaper article, etc.) from which the thought of a given collectivity (final product) will result.

The SR reconstructed by the investigator is the meaning that different social actors attribute to the world where they live. Interpretation of SR by the researcher is the meaning that he attributes to the meaning given by the social actors. Therefore, both tasks involve production of meaning.

\section{DCS BEYOND THE SCIENTIFIC DATA: DCS AS A POSSIBLE RESOURCE FOR SOCIAL INTERVENTION}

\section{Collective mirror}

A scientific production in the form of equation, chemical formula, bar chart, etc., is obviously a scientific product. However, this does not mean that all scientific production must have such presentation, or necessarily be far from reality. Furthermore, it is worth remembering that a mere distant appearance does not ensure that the results are scientific.

In the case of survey whose product is a SR or reconstitution of representations (such as collective products obtained with the use of artifacts, e.g., DCS), the results may appear as direct or non-distant things spontaneously identifiable by ordinary people as familiar thoughts or opinions that they could adopt.

This product can be seen as a sign of the type represented ${ }^{7}$ in the collective thought or opinion, since it seeks to bring to light not only the meaning of thought, but also the significant form of a statement, discourse or story.

Such significant form permits a widespread use of DCS in communication interventions. Through it, the receiver (or speaker) of the communication process can see and affectively identify himself/herself with the ideas, opinions, and arguments in a more intense way than when the survey results are presented in the conventional and distant form of graphs, charts, and tables.

From this identification, DCS can function as a "psychoanalytic mirror" of the thinking of col- lectivities and groups. Thus, it becomes a useful instrument for interventions such as awakening the collective consciousness and/or facilitating a dialogue with distinct attitudes or opinions.

\section{An example of communication intervention: the Morning-After Program}

Di@Seguinte (for Morning@fter) is a multimedia program, based on the results of the study "Pregnancy in adolescence and the morning-after pill. Unveiling their meanings among adolescents and health professionals" (project CNPq 550763/2007-4). This project was conducted in São Paulo (2007-2010) with 300 young people (male and female genders) and 70 health professionals (Municipality of São Paulo) who were responsible for health programs directed to young people and adolescents.

The study started from six cases or stories and aimed to describe SR of young people and professionals. Each was related to a particular aspect of problems associated with both sexuality and use of the morning-after pill.

Responses of young people and professionals were processed with the use of DCS. Finally, a significant number of DCS was obtained, showing in detail, the categories of opinion of this group on the study subject.

The program was prepared with DCS of these adolescents and was directed especially to young people. It is freely available since 2011 at www.tolteca.com.br.

The program begins with a presentation by the coordinator of the study, who describes the origin of the program and its mode of use. Then, a screen opens a window where the user can choose one of the six stories. The story is presented visually and orally. Then a "cartoon" version is presented with a musical background.

At the end from the cartoon version, the user is asked to choose an answer (which is presented visually and orally) among those given by the adolescent in study. After each response, the user has access to the comments by a health care professional, who presents technical positions with regard to the answers given by the other girls.

We present below an example of this dialog:

Case 3: A teenage girl was in love with a boy for a long time. As they loved each other very much, they could not resist and went to bed. The next day, the 
girl was very nervous because she believed she might be pregnant. Then, she told her friends, including her mother, who advised her to take the morning-after pill. However, she decided not to take the pill because she was a very religious person.

\section{If this religious teen asked you for advice, what would you say to her?}

We present below one of the categories of answers given to the adolescent and expressed as DCS:

She should take the pill to not get pregnant; probably this pregnancy is unwanted and thus there would be time to stop it, isn't it?

I would tell her to take the pill because this way she would not abort; she would be just protecting herself not to have an unwanted child since the pill does not kill any being. The pill is simply making ovulation not to happen or she would get pregnant. The pill is simply stopping ovulation that will actually generate a fetus, isn't it?

I would advise her to take the medicine [pill] and not get pregnant, because she would depend on her mother to raise her child. If she was dating or [only] going with for the first time, she should not have gone to bed with him. She should then take the pill because she was repented. She is not sure about what she wants, because she's new. She probably has not finished her studies. I would advise her to obey her mother and take the pill, because raising children is not a joke. It is not so: making children, and leaving them in the world. She must raise, educate, live with her child. In the life of a woman who becomes a mother, everyday life is completely different from that of a single person, who has more freedom to go out, enjoy, and have an entirely-free life.

Comments of the health professional:

I see that you have a mature view of this problem. It is important to know that emergency contraception is not abortive. I also think that adolescents who have this position could be multipliers of this information. I also agree that it is not worth sacrificing the future of everyone involved. The best is that everyone can prepare their future by studying and learning a good profession, bringing together conditions to constitute their families.

The program also presents a number technical information about the morning-after pill and its use.

The objective of the Morning@fter Program was to inform young people about various aspects related to the morning-after pill in the context of pregnancy problems during adolescence. Its particular feature is introducing young people, who access this program, different attitudes adopted by the young people in study regarding the use (or not use) of the morning-after pill.

This form of presentation was chosen to help program users identify their position and attitude towards the subject, access other possible positions, and compare any of them with the technical position of the health professional.

\section{III - CONCLUSION}

According to Vala in the book by R. Cabecinhas: "... claiming that representations are social involves the use of three criteria. 1. Quantitative criterion: a representation is social when it is shared by a group of individuals; 2 . Genetic criterion: a representation is social because it is collectively produced (resulting from the cognitive and symbolic activity of a social group); and 3. Functional criterion: a representation is social when it is used as a guide for communication and action (practical social theories)" $)^{8: 126}$

The SR are social-individual entities with power and practical cognitive function, as they function as guidelines for individuals to guide their usual interactions.

The basic purpose of creating the DCS technique was to personalize them (in agreement with the principles of SR) giving it a discursive subject able to speak while being spoken by them.

The "speaking/spoken" method allows us to describe and present representations according to the canons of scientific production while making these results useful, e.g., as effective resources for social intervention.

\section{ACKNOWLEDGEMENTS}

We warmly thank Eliane de Morais Bridget Falcon for her suggestions and criticisms.

\section{REFERENCES}

1. Jodelet D. Représentations Sociales: un domaine en expansion. In Jodelet D. organizador. Les Représentations Sociales. Paris (FR): PUF, 1989.

2. Herzlich C. A problemática da representação social e sua utilidade no campo da doença. Rev Saúde Coletiva. 2005; 15(Supl):57-70. 
3. Moscovici S. A representação social da psicanálise. Rio de Janeiro (RJ): Zahar, 1978

4. Lefevre F, Lefevre AMC. Depoimentos e discursos. Brasília (DF): Liberlivro,2005.

5. Lefevre F, Lefevre AMC. Pesquisa de Representação Social. Um enfoque qualiquantitativo. Brasilia (DF): Liberlivro, 2012.
6. Spink MJP. Análise de documentos de domínio público. Em Spink MJP (Org.), Práticas discursivas e produção de sentidos no cotidiano, São Paulo (SP): Cortez, 1999

7. Peirce CS. Semiótica e filosofia. São Paulo (SP): Cultrix/Edusp, 1975.

8. Cabecinhas R. Representações sociais, relações intergrupais e cognição social. Paidéia. 2004, 14(28) 